\title{
Ultrastructure of the Secretory Epithelial Cells of the Bulbo- Urethral Glands (Cowper's gland) in the Indian Fruit Bat, Rousettus leschenaulti (Desmarest) During the Reproductive Cycle
}

\author{
Ultraestructura de las Células Epiteliales Secretoras de las Glándulas Bulbouretrales \\ (glándula de Cowper) en el Murciélago de la India, Rousettus leschenaulti \\ (Desmarest) Durante el Ciclo Reproductivo
}

Archana A. Nerkar; Maher P. Gujar \& Mohan M. Gadegone

NERKAR, A. A.; GUJAR, M. P. \& GADEGONE, M. M. Ultrastructure of the secretory epithelial cells of the bulbo-urethral glands (cowper's gland) in the indian fruit bat, Rousettus leschenaulti (desmarest) during the reproductive cycle. Int. J. Morphol., 35(1):212-218, 2017.

SUMMARY: The present paper describes the ultrastructural characteristics of the bulbo-urethral gland (Cowper' glands) of the Indian fruit bat, $R$. leschenaulti during sexually inactive-breeding cycle. Cyclic histological changes during the seasonal breeding quiescence cycle are not well marked. There are no marked differences. The ultrastructural characteristic of the secretory epithelial cells of BulboUretrhal Gland gland have been studied during different phases of reproductive cycle. The secretory epithelial cells are characterized by the well-developed rough endoplasmic reticulum, extensive developed complexus golgiensis (Golgi apparatus) and mitochondria. Mitochondria with lamellate cristae are dispersed in the cytoplasm. Three different types of secretory granules can be identified on the basis of electron density. These granules are not of different types but they represent the different stages of granule maturation. The secretory products of bulbo-urethral gland of bat are released into lumen both by apocrine and merocrine modes. The functional significance of the secretions of the bulbo-urethral glands in reproduction is discussed.

KEY WORDS: Chiroptera; Bat; Ultrastructure; Bulbo-urethral gland; Acini; Epithelial cells.

\section{INTRODUCTION}

Considering the worldwide distribution and immense diversity exhibited by members of the order Chiroptera, remarkably limited attention has given to reproduction in the male. The details of the structure of the reproductive system are generally not described. Even less is known about the function and physiological control of reproduction in the male (Krutzsch, 2000). Male bats also exhibit diversity in the timing and frequency of their reproductive cycles annually. In some species this may be expressed in unique functional (dysynchronous) timing between primary and accessory sex glands (Krutzsch, 1979; Gopalakrishna \& Sapkal, 1986).

The male accessory organs show great plasticity in form and species distribution. These glands contribute various substances such as fructose, citric acid, sialic acid, proteins, zinc etc. to the ejaculate (Rajlakshmi \& Prasad, 1970; Mokkapati \& Dominic, 1976; Sapkal, 1986).

The light microscopic morphology of the accessory sex glands of chiroptera (Krutzsch, 2000) remains poorly known and only single report is available on the ultrastructure of the accessory sex glands of chiropteran bat, Artibeus planirostris (Puga et al., 2013). The aim of the present study is to document the ultrastructural changes in the bulbo-urethral gland (Cowper's gland) of Rousettus as it passes from the sexually quiescence into sexually active phase. This will facilitate future physiological studies and functional interpretations of this accessory gland of reproduction in bats. The periods of breeding and of sexual quiescence in Rousettus are known to occur between October-Februay and May-August respectively (Gopalakrishna \& Choudhari, 1977).

\section{MATERIAL AND METHOD}

The Indian fruit bat, $R$. leschenaulti (Desmarest) was selected for the present study. The specimens were collected from Nagpur (MS), India throughout the year representing different reproductive states. Adult males were trapped alive 
and were brought alive in the laboratory with minimum stress and constant supply of food and glucose water. Five bats each of the sexually quiescence, recrudescence and sexually active males were killed by cervical dislocation for light and electron microscopic study.

All these specimens were decapitated on being chloroformed and the bulbo-urethral glands were dissected out. For histological studies, bulbo-urethral gland was fixed in different fixatives like aqueous Bouins, Calcium acetate formalin (CAF), and neutral formalin. After fixation for 24 h, tissues were washed with $70 \%$ ethanol. For histological examination, the tissues were dehydrated through the graded series of ethanol, cleared in xylene and embedded in paraffin wax. Thin sections of 3-5 $\mu$ were cut with the help of Leica 2417 microtome and were stained with Ehrlich's Haematoxylin-eosin for histological observations.

For the electron-microscopic study, the bulbo-urethral glands were sliced into $1 \mathrm{~mm}$ pieces and were fixed in fresh ice-cold $3 \%$ glutaraldehyde for $3 \mathrm{~h}$ and then $4 \mathrm{~h}$ in $0.1 \mathrm{M}$ cacodylate buffer and then post fixed for $1-2 \mathrm{~h}$ in $1 \% 0.067$ M cacodylate-buffered osmium tetroxide. After dehydration with graded series of alcohol, the tissues were cleared in propylene oxide solution and embedded in Araldite resin which would be polymerized at 600C. Then, ultrathin sections from selected blocks were cut with glass knife and picked up on 400-mesh copper grids. Sections were double stained with $10 \%$ alcoholic uranyl acetate for $20 \mathrm{~min}$ and for 10 min in Reynold's lead citrate and examined under a JEM Jeol-100s electron microscope (Japan) at 80KU accelerating voltage and photographed.

\section{RESULTS AND DISCUSSION}

In Rousettus, bulbo-urethral glands are small, pear shaped, bilaterally symmetrical and are situated on either side of the base of penis. They are enclosed in a fibro muscular capsule and are separated into lobules by connective tissue and skeletal muscle septae that enter the gland from the capsule. Each lobule is made up of acini. The acini are secretory and each acinus is lined by columnar or pyramidal cells. During the sexually quiescent period (July), bulbourethral glands are slightly regressed. The acini are lined by low columnar cells with darkly stained basally to centrally placed nuclei. The cytoplasm and lumen show basophilic secretion. During the prebreeding (September) and the active breeding period (October), the acini are enlarged and are lined by tall columnar epithelial cells. The lumen of acinus contains a homogenous secretion. Regressive changes in the bulbo-urethral gland are evident from May. The acini and cells undergo gradual hypotrophy as the quiescent period approaches in June.

Bats collected in the month of July are sexually inactive and testis is aspermatogenic. The acini are secretory and each acinus is lined by pyramidal or low columnar cells with basally situated nuclei. Nucleus is round to oval or elongated containing one or two nucleoli. Heterochromatin clumps are distributed in the nucleoplasm and some chromatin material is seen adherent to the inner surface of nuclear envelope. Complexus golgiensis (Golgi apparatus) is well developed and is placed juxtanuclear in position. It consists of 5-6 Golgi lamellae, arranged parallely forming semicircle. The Golgi lamellae are curved and dilated. Associated with Golgi lamellae small secretory vesicles with electron lucent material and vacuoles containing electron dense material are present in the Golgi zone. Large numbers of coated vesicles are present near the Golgi lamellae as well as in apical cytoplasm. Rough endoplasmic reticulum is present associated with secretory vesicles. It is in the form of short and long lamellate cisternae dotted with ribosomes. Mitochondria are numerous and are distributed throughout the cytoplasm. They show lamellar cristae. Some mitochondria are vacuolated and show cristae at the periphery. Apical surface of the cells show many microvilli which are thick, short or elongated. These microvilli project into lumen. Some microvilli are seen lying free in the lumen. Junctional complexes are seen between two adjacent cells. Desmosomes are present on lateral membrane of two adjacent cells. In some cells basal plasma membrane shows interdigitations.

The secretory granules are numerous and are distributed throughout the cytoplasm. They show various degree of electron density. They are varying in shape and size. Secretory granules are oval to round shape. Three types of secretory granules can be identified based on their electron density. They are in different stages of maturation. The type1 secretory granules are few in number containing electron lucent material. The type- 2 secretory granules contain low electron dense material and type-3 secretory granules contain high electron dense material. In the cytoplasm large vacuoles are observed containing electron opaque to electron lucent materials. The electron dense secretory granules are seen just below the apical plasma membrane. Some of these fuse with apical plasma membrane and release their contents into lumen showing merocrine mode of secretion. Lumen shows scanty homogenous secretion. The secretory apparatus is very well developed in the acinar cells of bulbo-urethral gland during the inactive period (Figs. 1a and 1b).

Bats collected in the month of September are in recrudescence. The testis shows initiation of spermatogenesis 
and various stages of spermatogenesis up to spermatid formation and bats collected in the month of October and November, testis shows vigorous spermatogenesis. There are no marked differences in the ultrastructural features of bulbo-urethral gland during the active breeding period as compared to the bulbo-urethral gland of the prebreeding period. During these stages, acini of the bulbo-urethral gland are lined by tall columnar or pyramidal cells. Nucleus is
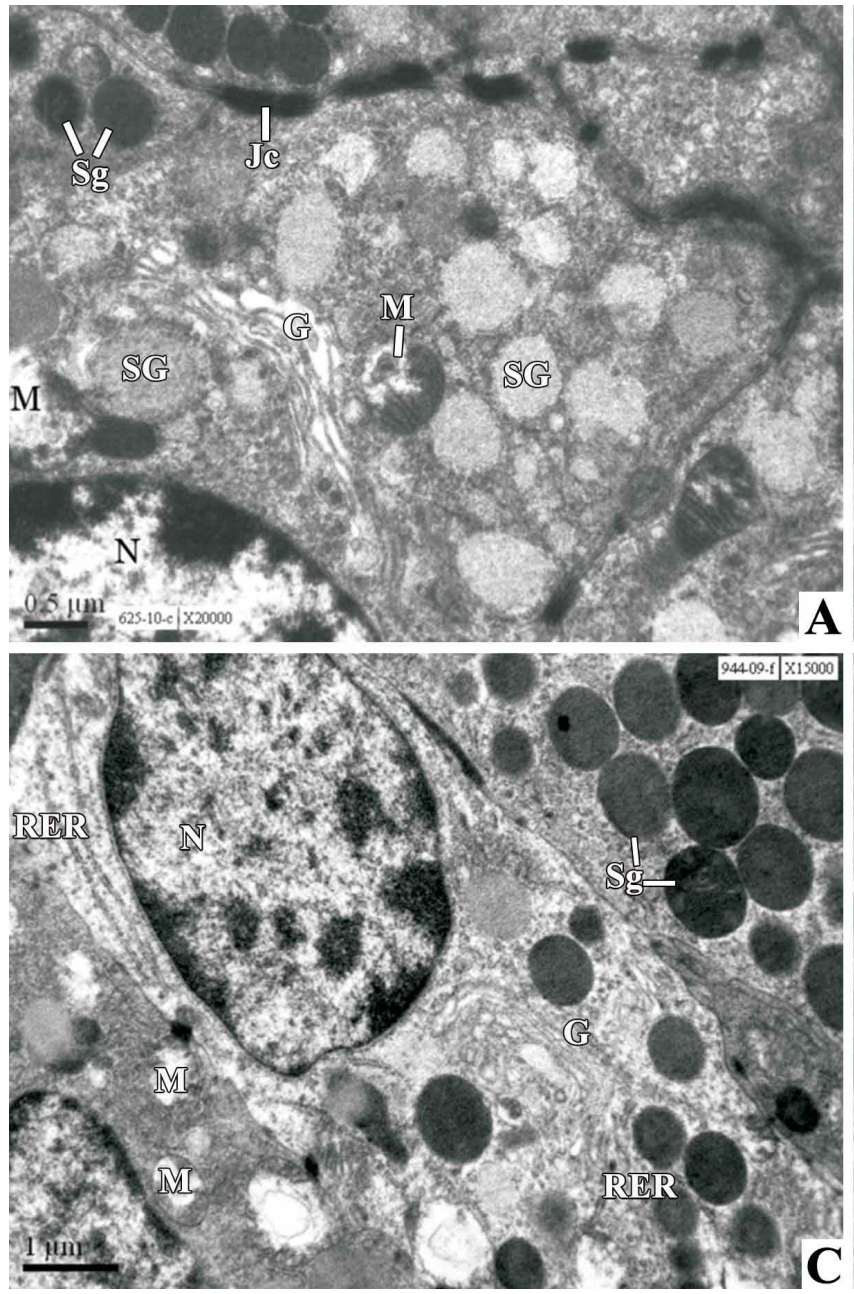

oval or round. Heterochromatin clumps are distributed in the nucleoplasm. Some of the chromatin material is seen attached to inner surface of the nuclear membrane. Complexus golgiensis is well developed. It is made up of 8 to 10 Golgi lamellae which are dilated arranged in parallel stacks. These lamellae are associated with large vacuoles containing electron lucent material (Fig. 1c and 1d). Mitochondria are round to rod shaped with lamellar cristae
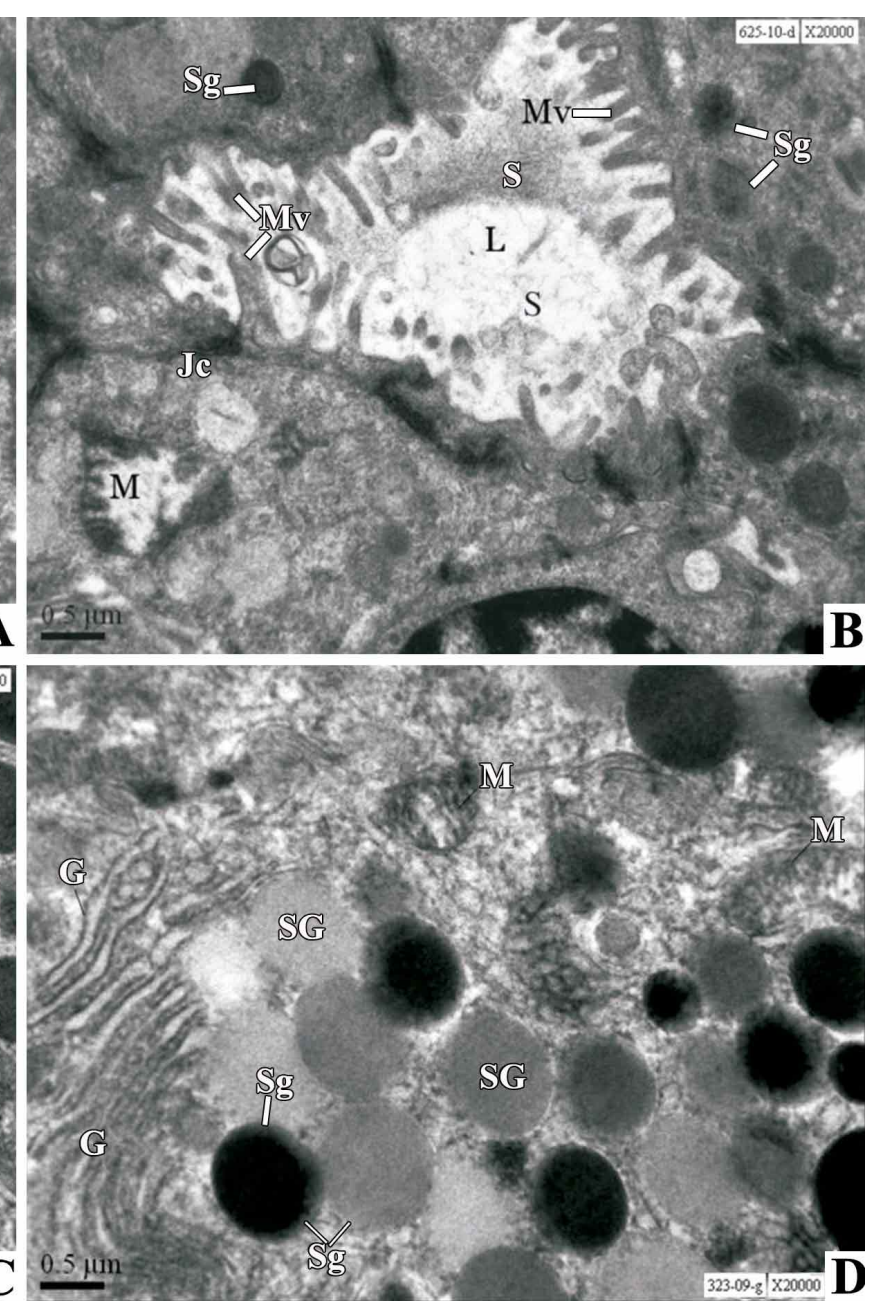

Fig. 1a. High power electron micrograph of acinar cells during the sexually inactive period showing well developed complexus golgiensis (G), mitochondria (M) near the Golgi and large number of electron lucent secretory granules (SG) and electron dense secretory granules (Sg) in the supranuclear part of the cytoplasm and also in the Golgi zone. Junctional complexes (Jc) are prominent between the two adjacent cells. X 20000. Fig. 1b. High power electron micrograph of acinar cells showing mitochondria (M) with lamellar cristae and junctional complexes (Jc). The electron dense secretory granules (Sg) lie below the apical plasma membrane and fuse with the apical plasma membrane releasing their content into the lumen. The luminar surface of acinar cells shows long and thick microvilli (Mv) projecting into the lumen (L). The lumen content homogenous electron dense and electron opaque secretion (S). X 20000

Fig. 1c. Electron micrograph of bulbo-urethral gland during prebreeding period showing acinar cell containing large basally placed nucleus (N). Complexus golgiensis $(\mathrm{G})$ is well developed. Coated vesicles are also seen in the Golgi zone. Mitochondria (M) with lamellar cristae are seen near Golgi. Apical cytoplasm is filled with electron moderately dense and highly electron dense secretory granules $(\mathrm{Sg})$ in the supranuclear cytoplasm. Rough endoplasmic reticulum (RER) in the form of short tubular and lamellar cisternae dotted with ribosomes are observed near the perinuclear part of the cytoplasm. X 15000.

Fig. 1d. Electron micrograph of the acinar cells of bulbo-urethral gland during the prebreeding period shows well developed complexus golgiensis (G). Mitochondria (M) are vesicular and elongated with lamellar cristae. Secretory granules with various electron densities are seen in the cytoplasm. X 20000. 
distributed throughout the cytoplasm. Some mitochondria show vacuolations and cristae are at the periphery. Rough endoplasmic reticulum (RER) is in the form of lamellar cisternae which are arranged in parallel form. Cisternae are seen surrounding the secretory granules in the cytoplasm. In some cells, lamellar cisternae are dilated and they show round to oval shapes dotted with ribosomes containing electron lucent material (Figs. 2a. and 2b).

As in the inactive period, the secretory granules are distributed throughout the cytoplasm. They are varying in shapes and sizes. Three different types of secretory granules depending on the electron density of secretory materials are: 1) Some secretory granules show electron opaque or lucent material. 2) Some secretory granules show low electron dense material and 3) some secretory granules show high electron dense material. The secretory granules containing electron dense material are at maximum level in active breeding period as compared to other two types of secretory granules. They are seen below the apical plasma membrane and some are seen releasing their content. Vacuoles containing amorphous material are seen in the cytoplasm. Lumen is filled with homogenous secretory material and some vacuoles containing amorphous material are seen in the lumen. In some cells the apocrine blebs are seen protruding into the lumen containing cytoplasmic matrix. Thus, secretory material is released into the lumen by apocrine and merocrine modes during pre-breeding and the active breeding period. The luminal surface of cell shows short microvilli protruding into the lumen. Junctional complexes are observed between the two adjacent cells (Figs. $2 \mathrm{a}, 2 \mathrm{c}$ and $2 \mathrm{~d})$.

Thus, during the different phases of sexual cycle, the ultrastructural features of acinar cells of bulbo-urethral gland show no marked differences in the secretory apparatus. The complexus golgiensis, rough endoplasmic reticulum and mitochondria are very well developed during allstages indicating the bulbo-urethral gland secretes metabolites even during the inactive period of the sexual cycle.

Cyclic histological changes in bulbo-urethral gland have been studies in few species of bats. They become hypertrophied and secretory with granular columnar epithelium in synchrony with the elevated testicular steroid cycle and involuted with cuboidal epithelium and agranular cytoplasm in the inactive testicular state in number of bat species, Nactyla noctula (Racey, 1974); Pipistrellus dormeri (Gadegone \& Sapkal, 1983); Taphozous melanopogon and Miniopterus (Gadegone et al., 1995); Brachyphylla cavemarum (Krutzsch \& Nellis, 2006); Hipposideros lankadiva (Gadegone et al., 2005); Brachyphylla cavemarum (Puga et al.); Myotis negricans (Negrin et al., 2014) and
Eidolon helvum (Danmaigoro et al., 2014). Similar cyclical changes in the histology of the bulbo-urethral gland of Rousettus have been reported in the present study. Our observations on bulbo-urethral gland are in conformation with the observations on bulbo-urethral gland of other bats.

There are no marked differences in ultrastructural characteristic of the secretory epithelial cells of bulbourethral gland of Rousettus during different stages of reproductive cycle. Ultrastructural differences between these secretory cells thus reflecting a secretory cycle into different phases of cellular activity and this may also result in the observed differences in the amount of secretion within the lumen.

The secretory epithelial cells of acini of bulbourethral gland are characterized by the well-developed rough endoplasmic reticulum with lamellate parallel profiles and dilated cisternae distributed throughout the cytoplasm. The complexus golgiensis is very extensive and is often the most conspicuous feature in the supranuclear portion of the cell. It is composed of highly dilated membranous sacs, small vesicles and vacuoles of various sizes. Some of the vacuoles contained finely granular material. Mitochondria with lamellate cristae are dispersed in the cytoplasm. The most prominent feature of the secretory cells is the presence of numerous secretory granules of various electron densities. The ultrastructural differences between these secretory cells may reflect differences in their physiological activity. Thus, the secretory cells of bulbo-urethral glands of bat, Rousettus show the ultrastructural characteristics which indicates that this gland is involved in synthesis and secretion of proteinaceous materials during the different phases of reproductive cycle. Similar secretory apparatus containing mitochondria, complexus golgiensis, endoplasmic reticulum and secretory granules has been reported in the secretory cells of bulbo-urethral gland of rat (Nielsen, 1976); human (Hellgren et al., 1982); Water buffalo (Abou-Elmagd \& Wrobel, 1989) and boar (Badia et al., 2005, 2006) supporting the present observations on bat.

Membrane bounded secretory granules of various sizes and densities are abundant in the Golgi zone and apical areas of secretory cells. Secretory granules appear to be formed by the large condensing vacuoles arising from the complexus golgiensis. Three different types of granules can be identified on the basis of electron density. It appears that these granules are not of different types but they represent the different stages of granule maturation. Immature granules are associated with complexus golgiensis and they are mostly seen during the inactive period. As they mature, they are carried towards the apical plasma membrane during prebreeding and breeding periods of bat. 

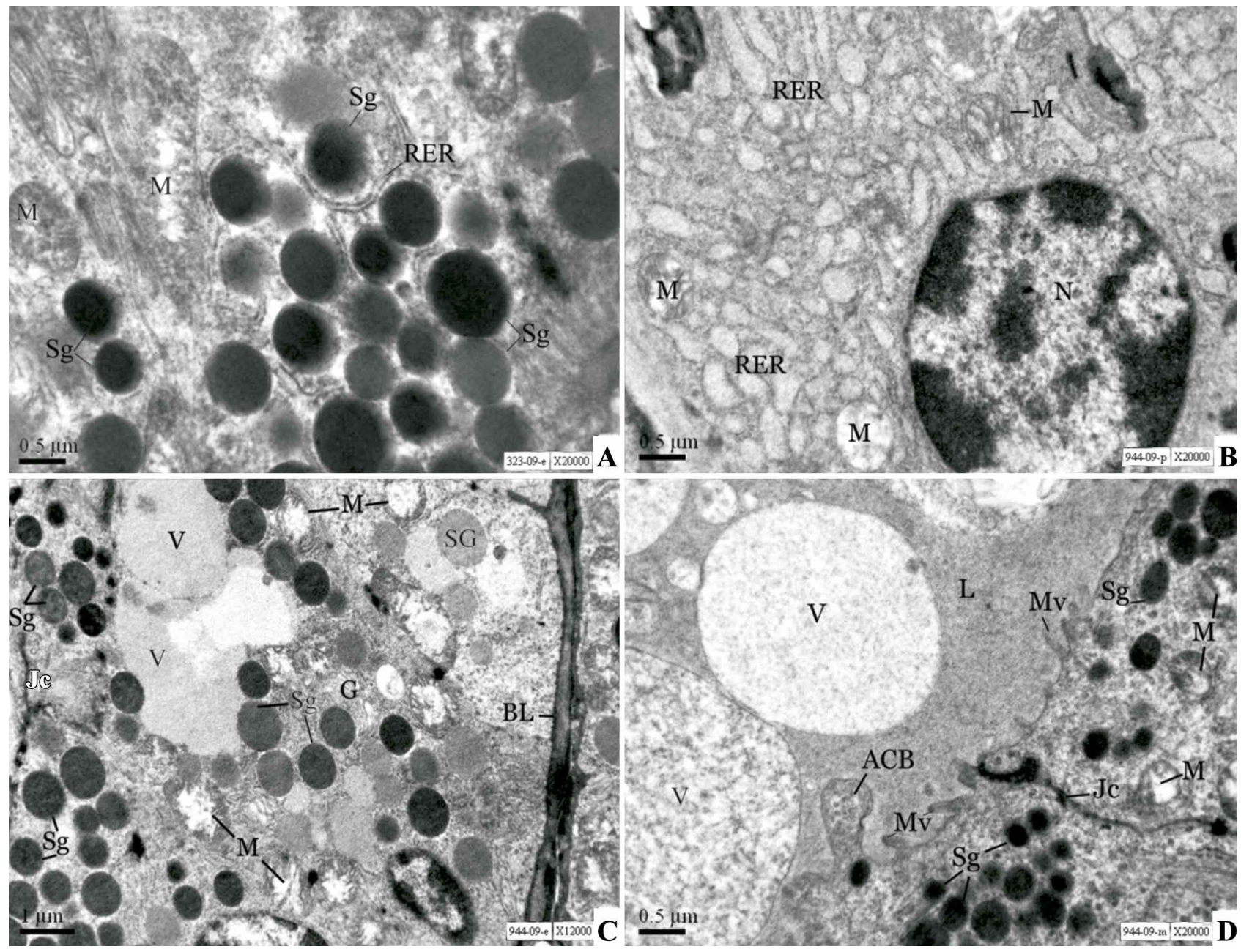

Fig. 2a. Electron micrograph of the acinar cells of bulbo-urethral gland during the prebreeding period showing large number of electron dense granules $(\mathrm{Sg})$ of various sizes and electron densities surrounded by cisternae of rough endoplasmic reticulum (RER). X 20000.

Fig. 2b. Electron micrograph of the acinar cells during the breeding period showing large nucleus (N) and Mitochondria (M) with lamellar cristae. Note that the cytoplasm is filled with dilated cisternae of rough endoplasmic reticulum (RER) containing electron lucent material. X 20000

Fig. 2c. High power electron micrograph of acinar cell during the breeding period showing moderately developed complexus golgiensis (G). Mitochondria (M) are numerous with lamellar cristae distributed throughout the cytoplasm. Two to three secretory granules fuse and form large vacuole (V) containing electron lucent secretory material. Large numbers of secretory granules (Sg) containing secretory material of various densities are seen. Junctional complexes (Jc) are seen on lateral side of adjacent cells. X 12000

Fig. 2d. Electron micrograph the acinar cells of bulbo-urethral gland during the breeding period showing short and thick microvilli (Mv) on the apical surface. Electron dense secretory granules ( $\mathrm{Sg}$ ) are seen below the apical plasma membrane releasing their content into the lumen (L). Apical cytoplasmic blebs (ACB) containing cytoplasmic matrix is seen projecting into the lumen. Lumen contains vacuoles (V) of various sizes bounded by membrane containing flocculent material and also homogenous electron dense secretions. Junctional complexes (Jc) are seen between lateral membranes of adjacent cells. X 20000

The secretion of the granules from cells into the acinar lumen takes place by exocytosis. In some acini, the apical surface of the secretory cells shows apical bulges which are protruded into the lumen containing secretory material. This secretory material then released into the lumen. In bulbo-urethral gland of Rousettus, release of secretory product into lumen both by apocrine and merocrine mode. The mode of secretion is merocrine in many mammals. However, apocrine and merocrine mode is reported in few mammals (Nielson, 1976; Hellgren et al.; Abou-Elmagd \& Wrobel; Badia et al., 2005) and bat (Gadegone et al., 2005). 
The luminal surfaces of the secretory cells of bulbourethral gland in Rousettus show microvilli. Junctional complexes, desmosomes and interdigitations are found between adjacent cells. The basal plasmalemma is usually relatively straight, but folding of this surface occasionally observed. The presence of microvilli may represent a form of micro apocrine secretion. Similar observations are reported in buffalo (Abou-Elmagd \& Wrobel).

The plasma testosterone concentration was assessed by radioimmunoassay in $R$. leschenaulti during different phases of reproductive cycle (Gujar, 2013). During the sexually inactive period the plasma testosterone concentration was $0.2 \mathrm{ng} / \mathrm{ml}$ and bulbo-urethral glands are regressed but the ultrastructural features indicate that the secretory cells of bulbo-urethral glands are synthetically active and synthesize secretory products. The concentration of plasma testosterone increases during prebreeding $(0.6 \mathrm{ng} /$ $\mathrm{ml}$ ) and the highest concentration of plasma testosterone is reported during the active breeding period in November (1.0 $\mathrm{ng} / \mathrm{ml}$ ). During these periods the bulbo-urethral glands are secretarialy very active as indicated by ultrastructural features of bulbo-urethral glands and synthesize large quantities of secretory products. Thus, it indicates that even small amount of testosterone during sexually inactive period stimulates synthesis of secretory products in bulbo-urethral glands of Rousettus (Mann, 1974).

In Rousettus, secretory cells of acini of bulbo-urethral gland during different phases of reproductive cycle show well developed complexus golgiensis and extensive development of rough endoplasmic reticulum and mitochondria indicate that these secretory cells are involved in synthesis and secretion of secretory products. Fructose, sialic acid and citric acid have been demonstrated in the secretory cells of bulbo-urethral glands of Rousettus (Sapkal); P. giganteus (Rajlakshmi \& Prasad) by biochemical method and neutral, sialic acid and sulfomucin in P. dormeri (Gadegone \& Sapkal); T. melanopogon and M. schreibersii (Gadegone et al., 1995) and H. lankadiva (Gadegone et al., 2005) by histochemical method. Ultrastructural features of secretory cells of bulbo-urethral gland of Rousettus support the synthesis of above cited metabolites as mentioned in other bats.

From the above discussion, it is suggested that secretory materials synthesis by bulbo-urethral gland of bat, Rousettus may be involved in various reproductive processes like maturation and survival of spermatozoa (Gupta, 1974), regulation of sperm metabolic activity and the maintaining of structural integrity of acrosomal and plasma membrane (Badia et al., 2005) and sperm egg interactions (TöpferPetersen, 1999). They may be involved in sperm-oviduct attachment which increases sperm viability, suppresses sperm motility and modulates the process of capacitation until egg is ovulated into the ampulla (Smith, 1998; TöpferPetersen). They may be also involved in semen coagulation and the formation of copulatory plug in the vagina and lubrication before ejaculation (Boursnell et al., 1970; Hart, 1968) and may be necessary for stabilization of the spermatozoon plasma membrane or may serve as a source of energy for spermatozoa and have protective functions for urethral epithelium (Chughtai et al., 2005).

\section{ACKNOWLEDGEMENTS}

The electron microscopy facilities provided by Dr. Arun Chitale, Department of Histopathology, Jaslok Hospital and Research Centre, Mumbai (MS), India are gratefully acknowledged. Our thanks are due to Mr. Dilip Kanaskar and Mr. Shivaji Bhosale for their excellent technical assistance.

NERKAR, A. A.; GUJAR, M. P. \& GADEGONE, M. M. Ultraestructura de las células epiteliales secretoras de las glándulas bulbouretrales (glándula de Cowper) en el murciélago de la india, Rousettus leschenaulti (desmarest) durante el ciclo reproductivo. Int. J. Morphol., 35(1) :212-218, 2017.

RESUMEN: El presente trabajo describe las características ultraestructurales de las glándulas bulbouretrales (glándulas de Cowper) del murciélago de la fruta de la India, R. leschenaulti durante el ciclo inactivo de reproducción sexual. Los cambios histológicos cíclicos durante el ciclo de quiescencia estacional de la cría no están bien determinados. No hay diferencias marcadas. La característica ultra estructural de las células epiteliales secretoras de la glándula bulbouretral ha sido estudiada durante diferentes fases del ciclo reproductivo. Las células epiteliales secretoras se caracterizan por un retículo endoplasmático rugoso bien desarrollado, el complexus golgiensis (complejo de Golgi) y mitocondrias desarrollados extensamente. Las mitocondrias con crestas lamelares se encontraron dispersas en el citoplasma. Se pueden identificar tres tipos diferentes de gránulos secretores en base a la densidad de electrones. Estos gránulos no son de tipos diferentes, sino que representan las diferentes etapas de maduración del gránulo. Los productos secretores de las glándulas bulbouretrales de murciélagos son liberados en el lumen tanto por modos apócrinos como merócrinos. Se discute la importancia funcional de las secreciones de la glándula bulbouretral en la reproducción.

PALABRAS CLAVE: Chiroptera; Murciélago; Ultrastructura; Glándula bulbouretral; Acinos, Células epiteliales. 


\section{REFERENCES}

Abou-Elmagd, A. \& Wrobel, K. H. The periurethral glandular complex in the water buffalo: an ultrastructural, histological and lectin-histochemical study. Arch. Histol. Cytol., 52(5):501-12, 1989.

Badia, E.; Pinart, E.; Briz, M.; Pastor, L. M.; Sancho, S.; Garcia-Gil, N.; Bassols, J.; Kádár, E.; Pruneda, A.; Bussalleu, E.; Yeste, M. \& Bonet, S. Lectin histochemistry of the boar bulbourethral glands. Eur. J. Histochem., 49(2):131-8, 2005.

Badia, E.; Briz, M. D.; Pinart, E.; Sancho, S.; Garcia, N.; Bassols, J.; Pruneda, A.; Bussalleu, E.; Yeste, M.; Casas, I. \& Bonet, S. Structural and ultrastructural features of boar bulbourethral glands. Tissue Cell, 38(1):7-18, 2006.

Boursnell, J. C.; Hartree, E. F. \& Briggs, P. A. Studies of the bulbo-urethral (Cowper's)-gland mucin and seminal gel of the boar. Biochem. J., 117(5):981-8, 1970

Chughtai, B.; Sawas, A.; O’Malley, R. L.; Naik, R. R.; Ali Khan, S. \& Pentyala, S. A neglected gland: a review of Cowper's gland. Int. J. Androl., 28(2):74-7, 2005.

Danmaigoro, A.; Onu, J. E.; Sonfada, M. L.; Umaru, M. A. \& Oyelowo, F. O. Histology and histometric anatomy of the male reproductive system of bat (Eidolon helvum). J. Histol., 2014: 834735, 2014.

Gadegone, M. M. \& Sapkal, V. M. Mucins in the male accessory sex glands of pipistrellid bat, Pipistrellus dormeri (Dobson). Comp. Physiol. Ecol., 8(3):219-22, 1983.

Gadegone, M. M.; Watkar, G. R. \& Sapkal, V. M. Histochemical observations on the male accessory reproductive organs of bats. III. Mucin in the Cowper's glands. Trends Life Sci., 10(1):1-9, 1985.

Gadegone, M. M.; Bhandarkar, W. R. \& Nerkar, A. A. Histochemical observations on the Cowper's glands of the Indian leaf-nosed bat, Hipposideros lankadiva (Kelaart). J. Adv. Zoo., 26 (1):35-40, 2005.

Gopalakrishna, A. A. \& Choudhari, P. N. Breeding habits and associated phenomena in some Indian bats. Part I - Rousettus leschenaulti (Desmarest) - Megachiroptera. J. Bombay Nat. Hist. Soc., 74:1-16, 1977.

Gopalakrishna, A. A. \& Sapkal, V. M. Breeding biology of some Indian Bats- A review. J. Bombay Nat. Hist. Soc., 83:78-101, 1986.

Gujar, M. P. Seasonal Changes in Plasma Testosterone Concentrations and Leydig Cell and Accessory Gland Activity in the Indian Fruit Bat, Rousettus leschenaulti (Desmarest). Ph.D. Thesis, Nagpur, Nagpur University, 2013.

Gupta, G. Sialic acid in the different regions of the epididymis and ductus deferens of the albino rat. J. Reprod. Fertil., 38(1):231-2, 1974.

Hart, R. G. The mechanism of action of Cowper's secretion in coagulating rat semen. J. Reprod. Fertil., 17:223-6, 1968.

Hellgren, L.; Mylius, E. \& Vincent, J. The ultrastructure of the human bulbo-urethral gland. J. Submicrosc. Cytol., 14(4):683-9, 1982.

Krutzsch, P. H. \& Nellis, D. W. Reproductive anatomy and cyclicity of the male Brachyphylla cavemarum (Chiroptera: Phyllostomidae). Acta Chirop., 8:497-507, 2006.

Krutzsch, P. H. Anatomy, Physiology and Cyclicity of the Male Reproductive Tract. In: Crichton, E. G. \& Krutzsch, P. H. (Eds.). Reproductive Biology of Bats. New York, Academic Press, 2000. pp.92-137.

Krutzsch, P. H. Male reproductive patterns in nonhibernating bats. J. Reprod. Fertil., 56(1):333-44, 1979.

Mann, T. Secretory function of the prostate, seminal vesicle and other male accessory organs of reproduction. J. Reprod. Fertil., 37(1):179-88, 1974.

Mokkapati, S. \& Dominic, C. J. Sites of production of fructose and citric acid in the accessory reproductive glands of three species of male chiropterans. Biol. Reprod., 14(5):627-9, 1976.

Negrin, A. C.; Beguelini, M. R.; Puga, C. C.; Christante, C. M.; Bueno, L. M.; Morielle-Versute, E.; Vilamaior, P. S. \& Taboga, S. R. Structure, histochemistry, ultrastructure and seasonal variations of the male prostatic complex in the black Myotis bat, Myotis nigricans (Chiroptera: Vespertilionidae). Reprod. Fertil. Dev., 26(8):1188-97, 2014.
Nielsen, E. H. The bulbourethral gland of the rat. Fine structure and histochemistry. Anat. Anz., 139(3):254-63, 1976.

Puga, C. C.; Beguelini, M. R.; Negrin, A. C.; Christante, C. M.; MorielleVersute, E.; Vilamaior, P. S. \& Taboga, S. R. Structure, histochemistry and ultrastructure of the male reproductive accessory glands in the neotropical flat-faced fruit-eating bat Artibeus planirostris (Chiroptera: Phyllostomidae). Reprod. Fertil. Dev., 25(3):558-69, 2013.

Racey, P. A. The reproductive cycle in male noctule bats, Nyctalus noctula. J. Reprod. Fertil., 41(1):169-82, 1974.

Rajlakshmi, M. \& Prasad, M. N. Sites of formation of fructose, citric acid and sialic acid in the accessory glands of the giant fruit bat, Pteropus giganteus giganteus (Brunnich). J. Endocrinol., 46:413-6, 1970.

Sapkal, V. M. Biochemical studies on the male accessory structures of Rousettus leschenaulti. Myotis, 24:79-86, 1986.

Smith, T. T. The modulation of sperm function by the oviductal epithelium. Biol. Reprod., 58(5):1102-4, 1998.

Töpfer-Petersen, E. Carbohydrate-based interactions on the route of a spermatozoon to fertilization. Hum. Reprod. Update, 5(4):314-29, 1999.

\author{
Corresponding author: \\ Dr. Archana A. Nerkar \\ Associate Professor \\ Reproductive Biology Section \\ Department of Zoology \\ Institute of Science \\ Civil Lines, R. T. Road \\ Nagpur 440001 (MS) \\ INDIA
}

Email: archnerkar@gmail.com

Received: 07-07-2015

Accepted: 14-11-2016 